\title{
Iklan dan Penggunaan Model Anak-Anak
}

\author{
Errika Dwi Setya Watie \\ (errika@ftik.usm.ac.id) \\ (Dosen Ilmu Komunikasi FTIK USM)
}

\begin{abstract}
Abstrak
There are many studies that prove how much influences ads on the audience, unfortunately there are many ads that it still violates Etika Pariwara Indonesia that has been determined. In the framework developed Lavidge and Steiner (1961) demonstrated the influence of the flow of mass communication. The framework has six steps from viewing the media audience to how does audience media act. Many ads using children as models of the ad. This is certainly allowed, but still have to pay attention to ethicsrelated, that in accordance with the view that there should be display ads in Indonesia.
\end{abstract}

\section{Kata Kunci : Periklanan, Anak-anak. Etika}

\section{PENDAHULUAN}

Kehadiran iklan merupakan hal yang saat ini tidak dapat dihindari dalam kehidupan sehari-hari. Iklan hadir di berbagai media dan berbagai ruang. Mulai dari media massa komersial hingga media-media yang seharusnya milik publik. Mulai dari ruang nyata hingga ruang maya di internet.

Ketidakmampuan orang yang hidup saat ini untuk menghindari iklan, membuat tampilan iklan seharusnya menjadi tampilan yang perlu dipertimbangkan dengan baik. Hal ini penting mengingat gempuran iklan yang terus menerus pada penontonnya berpotensi untuk turut membentuk pola pikir penikmatnya sekaligus mempengaruhi cara mereka melihat dan menghadapi dunia.

Telah banyak penelitian yang menunjukkan bagaimana iklan memiliki pengaruh pada penontonnya. Salah satunya adalah penelitian yang dilakukan Tarianna Ginting tahun 2011 dengan judul penelitian Pengaruh Iklan Rokok di Televisi Terhadap Perilaku Merokok. Penelitian tersebut menunjukkan bahwa tampilan yang ada pada iklan rokok terbukti mempengaruhi perilaku merokok siswa smp yang menjadi obyek penelitian tersebut (Ginting, 2011: 1).

Meskipun telah banyak penelitian yang membuktikan seberapa besar pengaruh iklan pada penikmatnya, sayangnya masih banyak iklan yang tetap saja melanggar etika pariwara dan hukum terkait yang telah ditetapkan. Para pembuat iklan meski telah mengetahui segala peraturan dan etika yang ditetapkan tetap saja masih banyak yang tidak memperdulikannya. Sebagai gambaran, ada 320 iklan yang melanggar etika, yang laporannya masuk kepada Badan Pengawas Perikanan PPPI dalam kurun waktu dari tahun 2009 hingga Oktober 2011.

\section{Pembahasan \\ LITERASI MEDIA}

Komunikasi massa merupakan satu level komunikasi yang melibatkan khalayak yang besar, heterogen, dan tersebar sebagai khalayak sasaran pesannya dengan menggunakan media-media yang bisa diakses massa secara massal.

Media massa dengan segala konten yang ditampilkannya, dewasa ini mendapat perhatian yang serius oleh para penggiat literasi media. Gerakan literasi media merupakan gerakan untuk memberikan pemahaman kepada para menikmat media 
terkait konten dalam media yang mereka lihat.

Pendidikan melek media bukan sekedar mengajarkan bagaimana mengoperasikan dan mengakses media, namun juga mengajarkan untuk secara kritis menganalisis, mengevaluasi tayangan yang layak tonton dan tayangan yang tidak layak tonton (Soyomukti, 2010:195). Berdasar berbagai penelitian yang telah membuktikan besarnya pengaruh tampilan media pada khalayaknya, jelas menunjukkan bahwa literasi media penting untuk digerakkan agar apa yang ditampilkan pada media lebih terkontrol oleh para penikmatnya secara langsung.

Dalam bingkai kerja yang dikembangkan Lavidge dan Steiner (1961) ditunjukkan alur pengaruh komunikasi massa. Bingkai kerja tersebut memiliki enam langkah dari mulai tampilan media khalayak hingga khalayak bertindak. Enam langkah tersebut adalah kesadaran, pengetahuan, kesukaan, pilihan, petnyataan, dan pembelian/ tindakan nyata. Keenam langkah tersebut terbagi menjadi tiga dimensi pemahaman yaitu mulai dari dimensi kognitif yang merujuk pada pemikiran atau gagasan, dimensi afektif yang merujuk pada emosi khalayak, hingga dimensi konatif yang merujuk pada motivasi khalayak (Severin \& Tankard, 2007: 15-16)

\section{IKLAN}

Dunn dan Barban (1978) menuliskan, bahwa iklan merupakan bentuk kegiatan komunikasi non personal yang disampaikan lewat media dengan membaya ruang yang dipakainya untuk menyampaikan pesan yang bersifat membujuk (persuasive) kepada konsumen, oleh perusahaan, lembaga non-komersial, maupun pribadi yang berkepentingan7..2 Dalam iklan terdapat enam prinsip dasar, yaitu : 1) ada pesan tertentu, 2) dilakukan komunikator, 3) dilakukan secara nonpersonal, 4) disampaikan untuk khalayak tertentu, 5) dilakukan dengan cara membayar, 6) mengharapkan dampak tertentu dari penyampaian pesan yang dilakukan (Widyatama, 2007:15-24).

Iklan dalam upayanya menarik perhatian konsumen, tak jarang harus melakukan pengolahan baik verbal maupun non verbal dalam kontennya sehingga sedapat mungkin menarik dan mudah diingat.

\section{ETIKA PARIWARA INDONESIA}

Tujuan iklan yang harus mempersuasi penontonnya ini membuat para pembuat iklan untuk menciptakan iklan yang kreatif dan semenarik mungkin. Sayangnya, karena persaingan yang semakin ketat, dan tuntutan iklan tampil menarik dan menonjol yang semakin kuat, membuat para pembuat iklan lupa akan adanya etika pariwara Indonesia. Etika pariwara Indonesia adalah susunan aturan etika yang menjadi rambu-rambu bagi para pembuat iklan untuk menciptakan iklan yang sesuai bagi budaya dan karakter masyarakat Indonesia.

Dalam Etika Pariwara Indonesia, atau yang sering disebut dengan EPI, salah satunya mengatur tentang bagaimana iklan untuk produk dengan khalayak anak dibuat dan tentang bagaimana penggunaan anak-anak sebagai model iklan. Pada Bab III tentang ketentuan tata krama :

1.27 Khalayak Anak-anak

1.27.1 Iklan yang ditujukan kepada khalayak anak-anak tidak boleh menampilkan hal-hal yang dapat mengganggu atau merusak jasmani dan rohani mereka, memanfaatkan kemudahpercayaan,

kekurangpengalaman, atau kepolosan mereka.

Film iklan yang ditujukan kepada, atau tampil pada segmen waktu siaran khalayak anak-anak dan menampilkan adegan kekerasan, aktivitas seksual, bahasa yang tidak pantas, dan atau dialog 
yang sulit wajib mencantumkan kata-kata "Bimbingan Orangtua" atau simbol yang bermakna sama.

\section{Pemeran Iklan}

3.1 Anak-anak

3.1.1 Anak-anak tidak boleh digunakan untuk mengiklankan produk yang tidak layak dikonsumsi oleh anakanak, tanpa didampingi orang dewasa.

3.1.2 Iklan tidak boleh memperlihatkan anak-anak dalam adegan-adegan yang berbahaya, menyesatkan atau tidak pantas dilakukan oleh anakanak.

3.1.3 Iklan tidak boleh menampilkan anak-anak sebagai penganjur bagi penggunaan suatu produk yang bukan untuk anak-anak.

3.1.4 Iklan tidak boleh menampilkan adegan yang mengeksploitasi daya rengek (pester power) anak-anak dengan maksud memaksa para orang tua untuk mengabulkan permintaan anak-anak mereka akan produk terkait.

(Etika Pariwara Indonesia, 2007)

\section{IKLAN DAN ANAK-ANAK}

Saat ini, banyak iklan yang menggunakan anak-anak sebagai model iklannya. Baik untuk produk dengan sasaran konsumen anak, maupun produk dengan sasaran konsumen yang bukan anak-anak. Hal ini tentunya diperbolehkan, namun tetap harus memperhatikan etika terkait, agar tampilan yang ada sesuai dengan tampilan iklan yang sebaiknya ada di Indonesia.

Sayangnya, banyak pembuat iklan yang saat ini lupa atau bahkan mungkin tidak lagi mempertimbangkan, bahwa ada aturan tentang bagaimana anak ditampilkan dalam iklan. Sebagai contoh lihatlah tampilan iklan salah satu produk provider seluler yang menggunakan model anak. Dalam iklan tersebut anak ditampilkan seolah sedang diwawancarai dan dengan polos memberikan jawabannya.

Antonius Ipur dalam tulisan Sumbo Tinarbuko mengatakan bahwa iklan operator seluler 3 "always on versi anak kecil" secara visual memanipulasi dan melakukan dehumanisasi anak-anak lewat tayangan tersebut. Iklan ini menurut Tinarbuko melanggar EPI pasal 3.1 tentang pemeran anak-anak, terutama pasal 3.1.1 dan 3.1.3. (Tinarbuko, 2013).

Juli 2013, KPI pun telah melayangkan surat peringatan tertulis pada tujuh stasiun televisi terkait ditayangkannya iklan 3 versi anak kecil. Peringatan ini dilayangkan berdasar laporan yang diterima dari PPPI atas pelanggaran EPI dalam iklan tersebut.

Iklan lain yang melanggar etika pariwara adalah iklan salah satu biscuit yang menampilkan tampilan anak-anak yang sedang naik bis bersama temannya lalu melemparkan biscuit tersebut keluar jendela kemudian biscuit tersebut diterima temannya yang lain dengan mulutnya dengan cara menjulurkan kepala keluar jendela. Jelas iklan tersebut melanggar EPI pasal 3.1.2 yang menyebutkan bahwa Iklan tidak boleh memperlihatkan anakanak dalam adegan-adegan yang berbahaya, menyesatkan atau tidak pantas dilakukan oleh anak-anak.

Sosok anak-anak menjadi perhatian dalam artikel ini, karena serapan pemahaman mereka akan tayangan televisi, dalam hal ini iklan masih perlu dilindungi. Anakanak adalah peniru ulung tiap apa yang dilihatnya menarik. Bayangkan saja jika anak-anak yang menyaksikan iklan biscuit diatas dan menirukan adegan menjulurkan kepala keluar bis yang sedang melaju. Betapa mengerikan dan berbahaya jika hal tersebut dilakukan.

Iklan lain lagi yang hendaknya perlu mendapat perhatian yaitu iklan minuman kemasan yang menampilkan model anak yang mengatakan tentang bagaimana kondisi seorang yang sendiri, tanpa ada 
gandengan, serta iklan margarine yang menampilkan model anak yang memilikirkan memilih kerja atau menikah dahulu. Adagen dalam iklan tersebut menampilkan model anak yang tidak berpikir sewajarnya seperti seharusnya masa tumbuh kembang alami anak.

Begitu juga adegan anak-anak yang "dipaksa berpikir dewasa" sebagaimana yang ada dalam iklan provider diatas. Masa tumbuh kembang alami mereka dipaksakan untuk berpikir, berucap kata, yang belum pantas dipikirkan dan diucapkan. Belum sesuai dengan masa tumbuh kembangnya. Hal ini jika terlanjur terdoktrin ke masyarakat, bahwa yang benar adalah apa yang ada dalam iklan tersebut, akan berpotensi membuat masyarakat berpikir bahwa anak yang tidak bisa berpikir sebagaimana yang ditampilkan dalam iklan tersebut adalah anak yang tertinggal dalam tumbuh kembangnya. Padahal justru yang belum seperti apa yang ditampilkan dalam iklan itulah yang seharusnya terjadi, justru itulah yang normal. Anak-anak kemudian dipaksa untuk sama dan hasilnya masa kecil merekapun hilang terkeksploitasi karena tampilan yang salah yang telah terlanjur terdoktrin di masyarakat.

\section{PENUTUP}

Dua contoh diatas adalah dua contoh iklan yang teramati oleh penulis, namun tak menutup kemungkinan bahwa masih ada iklan lain yang juga melanggar ketentuan dalam EPI, terutama terkait bagaimana anak-anak ditampilkan dalam iklan. Contoh-contoh diatas menunjukkan nilai pentingnya EPI sebagai rambu-rambu dalam pembuatan iklan diperhatikan lagi oleh pembuat iklan.

Artikel ini memfokuskan perhatian pada tampilan anak-anak dalam iklan, bahwa kesadaran kita sendiri sebagai penikmat iklan akan tampilan anak-anak dalam iklan perlu diasah terus, sehingga tampilan anak dalam iklan tidak dipaksa tampil tidak sesuai dengan kondisi yang seharusnya mereka. Anak dalam iklan hendaknya ditampilkan sebagaimana bagaimana anak tampil secara alami.

Pembuat iklan dan semua pelaku yang pencipta iklan hendaknya juga menyadari pentingnya EPI untuk diindahkan, agar tidak menjadi boomerang bagi dirinya sendiri, karena efek dan dampak yang ditimbulkan bisa kembali secara langsung maupun tidak langsung ke dirinya. Masa depan gambaran anak yang wajar, salah satunya dikendalikan oleh apa yang ditampilkan di media, termasuk pada iklan. Kesadaran akan dampak iklan yang kurang tepat tampilannya juga hendaknya tetap jadi pegangan dalam menciptakan suatu iklan. Disinilah kesadaran akan penggunaan EPI wajib untuk dipegang semua pelaku dunia iklan.

\section{DAFTAR PUSTAKA}

Pengantar Ilmu Komunikasi, Nurani Soyomukti, 2010. Yogyakarta. ArRuzz Media

Werner J. Severin \& James W Tankard, Jr. Teori Komunikasi: Sejarah, metode, \& Terapan di dalam media massa. Edisi 5. Jakarta: Kencana. 2007

http://sumbotinarbuko.com/dehumanisasianak-dalam-iklan.html, diakses tanggal 22 Oktober 2013

Widyatama, Rendra, Pengantar Periklanan, Yogyakarta: Pustaka Book Publisher, 2007.

http://www.kpi.go.id/index.php/lihatsanksi/31520-peringatan-tertulisuntuk-11-stasiun-tv-perihal-iklantri-indie-semua-versi-versi-anaklaki-laki-dan-anak-perempuan, diakses tanggal 22 Oktober 2013 